\title{
Teaching as Brain Changing: Exploring Connections between Neuroscience and Innovative Teaching
}

\author{
Melinda T. Owens and Kimberly D. Tanner*
}

Science Education Partnership and Assessment Laboratory, San Francisco State University, San Francisco, CA 94132

$\mathrm{H}$ ow do you conceptualize learning? Do you think of learning as a contractual agreement: the instructor performs certain actions to facilitate learning, and the student, in turn, explicitly or implicitly promises to behave in ways to receive that learning? Or do you think of learning in sociological terms: the learner, through what he or she learns, transforms his or her beliefs and becomes a more emancipated citizen of the world? Or perhaps you think of learning in psychological terms: learners are motivated, store facts in their minds, and create mental knowledge structures. All of these ways of conceptualizing learning can be beneficial in understanding how students learn and what makes teaching effective.

However, at their most fundamental and mechanistic level, teaching and learning are neurological phenomena arising from physical changes in brain cells. The notion that learning and memory are neurobiological processes is relatively young, dating back only to the 18th century (Hartley, 1749). Even today, only about half of teachers and the general public, depending on the country, agree that "learning occurs through the modification of the brain's nervous connections" (Herculano-Houzel, 2002, p. 102; Howard-Jones et al., 2009; Deligiannidi and Howard-Jones, 2015; Hermida et al., 2016). Nevertheless, recent advances in brain science have given us an in-depth picture of the molecular and cellular changes that occur during learning, and the consensus of neurobiologists is that these alterations are both necessary and sufficient for the formation of memories (Takeuchi et al., 2014).

If anyone should appreciate that teaching and learning are biological phenomena, one would predict it would be biologists, and scientists more generally. However, few of us were likely taught about the neurobiology of learning in our pedagogical training. In this paper, we will first explore how one might conceptualize learning as a biological process in the context of a common teaching technique called the thinkpair-share. Then, we will give an overview of what is known from biological research about the neurobiological basis of learning and explore how various teaching techniques might harness known neurological mechanisms to promote the creation and retrieval of long-term memories. This Feature does not aspire to give instructions for how one should teach. Certainly, there have been many attempts to use the findings of neuroscience to create guidelines for instruction, particularly in K-12 education, and even to sell "brain-based curricula," but given the complexity of human learning, many neuroscientists believe these attempts have been at best premature and, at worst, "distortions" of the science (Bruer, 2006; Goswami, 2006; James S. McDonnell Foundation, 2007; Howard-Jones, 2014). Instead, we aspire to connect what is known in neurobiology to what is known from science education research about how innovative teaching is effective at promoting learning (Freeman et al., 2014).

A NEUROBIOLOGICAL CONCEPTUALIZATION OF THE THINK-PAIR-SHARE Each of our students arrives in class with a human brain, which on average has 86 billion neurons arranged in hundreds of brain regions, each with different

CBE Life Sci Educ June 1, 2017 16:fe2 DOI:10.1187/cbe.17-01-0005

*Address correspondence to: Kimberly D. Tanner (kdtanner@sfsu.edu).

(c) 2017 M. T. Owens and K. D. Tanner. CBE-Life Sciences Education () 2017 The American Society for Cell Biology. This article is distributed by The American Society for Cell Biology under license from the author(s). It is available to the public under an Attribution-Noncommercial-Share Alike 3.0 Unported Creative Commons License (http://creativecommons.org/licenses/ by-nc-sa/3.0).

"ASCB®" and "The American Society for Cell Biology ${ }^{\circledR}$ are registered trademarks of The American Society for Cell Biology. 


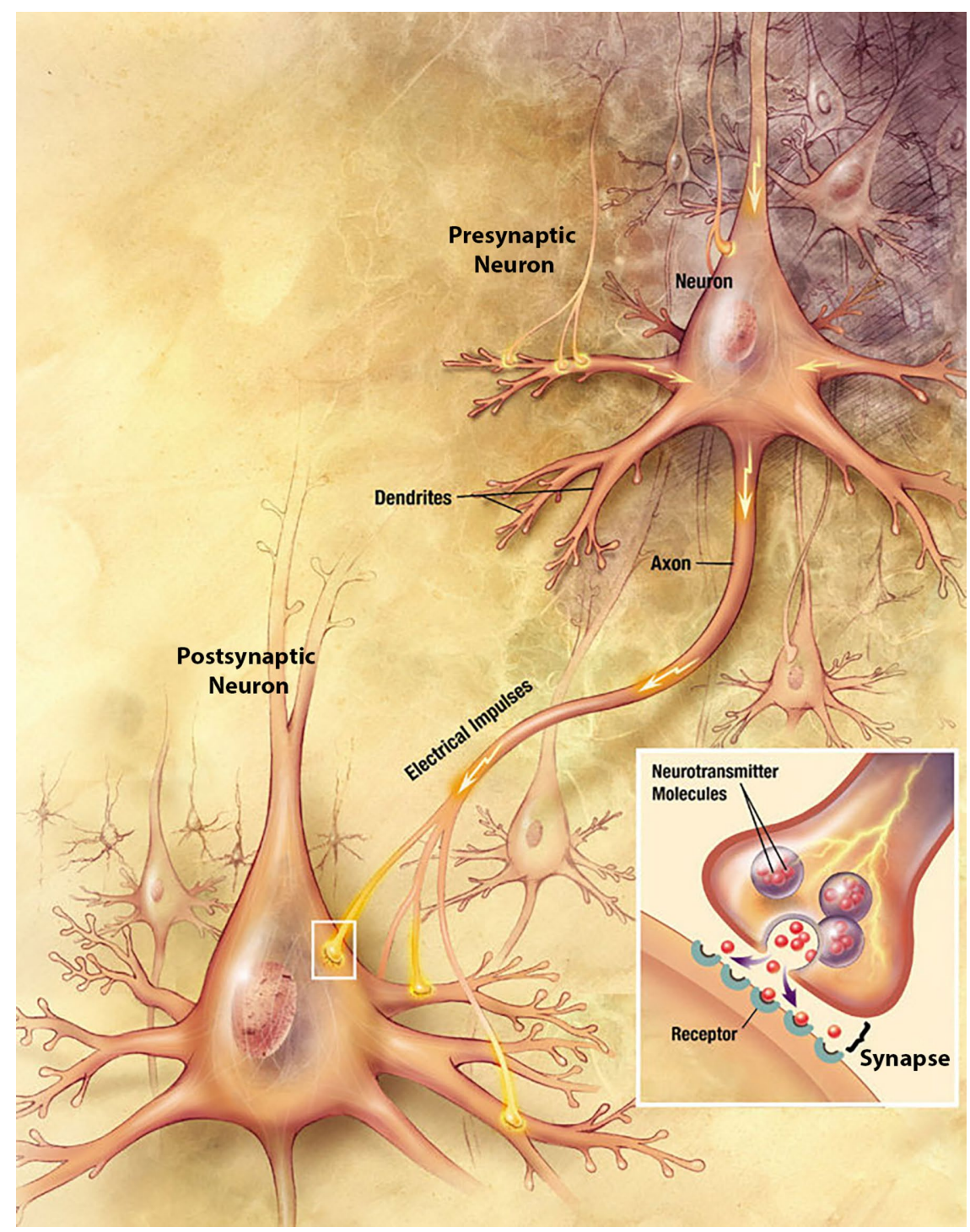

FIGURE 1. Anatomy of two representative neurons in the brain and a synapse between them. Path of electrical current indicated with yellow arrows. Inset, close-up view of the synapse. Illustration adapted from Alzheimer's Disease Education and Referral Center, National Institutes on Aging, U.S. National Institutes of Health (www.nia.nih.gov/ Alzheimers/Publications/UnravelingtheMystery).

functions (Azevedo et al., 2009). These neurons connect with one another to form neural circuits, making an estimated 100 trillion contacts with one another, called synapses (Williams and Herrup, 1988). Although there is much that we do not understand about how the brain functions, we do know that brains are always active, always analyzing and responding to a myriad of internal and external cues, both consciously and subconsciously. As an example, if we could look inside student brains as they are learning through participating in a common nonlecture classroom activity, the think-pair-share, what might we see?

Imagine a class full of students. In a think-pair-share, they all think individually about a solution to a problem, pair with a neighbor to discuss their ideas, and share their thoughts with a larger group (Lyman, 1981; Tanner, 2009b). Although this technique is relatively easy to implement, its apparent simplicity belies the deeper intricacies of the tasks the students' brains must do to accomplish it. During the think phase, to be most effective, the students' task must pique their interest and motivate them to pay attention to the concept under study. That attention might cause the release of chemicals in the brain, such as particular types of neurotransmitters, which carry signals between synapses, that promote learning (Everitt and Robbins, 1997; Schultz and Dickinson, 2000). The task may also tie the concept to other topics from the class or from real life, challenging the students and the brain cells within them to form the associations that can aid long-term memory formation and retrieval. In the next phases, the pair and the share, the students discuss the task with peers, practicing the skills and habits of thought necessary to master the subject. During this phase, the students have the confidence to complete this activity with a community of supportive peers. These feelings of confidence and community may also promote learning indirectly by preventing the release of chemicals in the brain and body, such as stress hormones, that could inhibit learning (Lupien and McEwen, 1997; de Kloet et al., 1999).

Thus, all of the phases of the thinkpair-share are in service to the ultimate goal, encoding memory in synaptic connections and neural circuits. Hopefully, the think-pair-share has caused the connections between nerve cells inside the students' brains to be changed for a long time, allowing them to recall the solution to the task months later and perhaps for the rest of their lives. So, how exactly do neurons and synapses change when a memory is created and retrieved? Below, we delve into the neurobiology of learning on a more detailed level to illuminate the changes that may be occurring in students' brains as they learn.

\section{HOW DO TWO NEURONS COMMUNICATE WITH EACH OTHER?}

The consensus among neuroscientists is that the basis of learning and memory creation lies in changes in electrically active nerve cells, called neurons, and the connections between them, the synapses. Although neurons come in many diverse shapes, a stereotypical example of two neurons is shown in Figure 1. Neurons have many thin projections extending from the cell body, called dendrites and axons (Figure 1). In general, dendrites receive signals from the outside world or from other neurons, and axons send signals to other neurons or to muscles or glands. 
When a neuron's dendrites are adequately stimulated, an electrical signal flows down the dendrites, through the cell body, and down the axon (Figure 1). Colloquially, this process is referred to as firing.

At the synapse, this electrical signal is passed onto other neurons. However, most of the time, the signal cannot be passed on directly, because the end of an axon is usually very close to part of another neuron's dendrite but is not directly continuous with it (Figure 1). Therefore, to propagate the signal, the sending neuron, the presynaptic neuron, must convert the electrical signal to a chemical signal before it can be sent to the receiving neuron, the postsynaptic neuron. In other words, in response to electrical stimulation, presynaptic neurons release neurotransmitters that carry the cellular signal across the synaptic gap. There are dozens of different types of neurotransmitters, each with different possible effects, and the neurotransmitter(s) released at a particular synapse depends on the identity of the presynaptic neuron. After release, the neurotransmitters diffuse across the synapse and bind to receptors on (or in) the postsynaptic cell (Figure 1). When a neurotransmitter binds to a receptor, it directly or indirectly creates or modulates an electrical signal in the postsynaptic neuron, perhaps causing it to fire. A postsynaptic neuron might have tens of thousands of presynaptic neurons of different types synapsing onto it (Megias et al., 2001). This system of using chemical neurotransmitters to send signals across synapses to alter the postsynaptic neuron's behavior allows for the postsynaptic neuron to integrate all the signals it receives and produce sensible behavioral responses to complex environmental stimuli.

\section{HOW DOES THE BRAIN CHANGE THROUGH SYNAPTIC PLASTICITY? NEURONS THAT FIRE TOGETHER, WIRE TOGETHER}

While the basic architecture of the human brain is set up early in childhood, learning and memory is possible because individual neurons retain the ability to change their signaling and synaptic connections throughout a person's life. Brain changes have been observed in neurons and synapses both after extreme changes in sensory experiences, like blindness, and after more subtle ones, like navigating a maze for the first time (Wiesel and Hubel, 1963; Karlsson and Frank, 2008). For the most part, brain changes do not seem to arise from the birth of new neurons, called neurogenesis. While neurogenesis does occur in the adult human brain, it only does so in certain brain areas, and newly born neurons represent only $\sim 0.004 \%$ of the of the total population of neurons at any given time (Bhardwaj et al., 2006; Bergmann et al., 2012; Spalding et al., 2013).

Instead, learning appears to occur primarily because of changes in the strength and number of the connections between existing neurons, a process called synaptic plasticity. For the most part, the changes occur in such a way that frequently used connections between neurons are enhanced the most. If the activation of a presynaptic neuron causes a postsynaptic neuron to fire, the neurons will alter themselves molecularly and cellularly so that the presynaptic neuron becomes even better at triggering the firing of the postsynaptic neuron (Hebb, 1949; Takeuchi et al., 2014). For example, in the short term, more neurotransmitter receptors may be inserted into the membrane of the synapse of the postsynaptic neuron, making it more receptive to the presynaptic neuron's signals, and in the long term, new synapses between the two neurons may grow (Holtmaat and Svoboda, 2009; Takeuchi et al., 2014). If the coactivation of two neurons happens repeatedly, these new synapses can last for long periods of time, providing a neural substrate for long-term memory. The principle that that coactivation of two neurons leads to a stronger connection between those neurons was pithily summarized in the early 1990s by neuroscientist Carla Shatz as, "Neurons that fire together, wire together" (Shatz, 1992).

\section{HOW DOES SYNAPTIC PLASTICITY RELATE TO LEARNING AND MEMORY?}

Researchers have repeatedly shown that neural connections in many different parts of the brain can change and that this synaptic plasticity is associated with and leads to behavioral learning and the formation of memories. For instance, neuroscientists found that training mice in a novel motor task induced an outgrowth of new synapses very quickly, within an hour, in the motor cortex, a part of the brain dedicated to planned movements. Furthermore, they found that further training stabilized some of the new synapses so that they remained present for weeks, months, and possibly years (Xu et al., 2009; Yang et al., 2009). We also know that blocking specific processes and molecules important for synaptic plasticity, such as particular neurotransmitter receptors, prevents behavioral learning, giving a causal connection between synaptic plasticity and learning (Morris et al., 1986). These are just some of the thousands of studies in all sorts of animal models that link synaptic plasticity between neurons to the changes in behavior that indicate learning and memory formation (Takeuchi et al., 2014).

\section{WHAT CAN AFFECT THE ABILITY OF NEURAL CONNECTIONS TO CHANGE?}

Although nearly all neural connections have the ability to exhibit plasticity, there are multiple factors that can either promote or inhibit neural change. Some of the same processes that alter one's ability to learn are also associated with neurochemicals that affect synaptic plasticity. For example, we all know that it is easier to learn something if we are paying attention and motivated by the material. Scientists have identified a set of neurotransmitters that are commonly released in contexts involving motivation and attention. Broadly speaking, the neurotransmitter dopamine is associated with reward or the anticipation of reward, while the neurotransmitter acetylcholine (ACh) is released during situations of novelty or surprise (Everitt and Robbins, 1997; Schultz and Dickinson, 2000). Unsurprisingly, blocking either neurotransmitter impairs synaptic plasticity, while the presence of either neurotransmitter enhances it (Conner et al., 2003; Reed et al., 2011; Froemke et al., 2013; Takeuchi et al., 2014). On the basis of these laboratory studies, neuroscientists would predict that when our students are motivated and attentive in our class, their brains are releasing dopamine and ACh, priming them for plasticity and learning.

On the flip side, there are other factors that can inhibit plasticity. Everyone has felt how a stressful or scary event causes heart rates and blood pressures to rise. It turns out that some of the same chemicals that are involved in the body's response to fear and stress also pass into the brain and can profoundly affect processes there. One chemical in particular, the stress 
hormone cortisol, seems to be particularly relevant to plasticity and learning. The brain is rich in receptors for cortisol, especially in areas relevant to memory (de Kloet et al., 1999). While mild elevations in cortisol can boost performance on memory tests, high levels inhibit both the encoding and the retrieval of memory in both animals and humans (Lupien and McEwen, 1997; de Kloet et al., 1999). Synaptic plasticity follows the same pattern, wherein high levels of cortisol disrupt the strengthening of connections between synapses (de Kloet et al., 1999). The negative effects of high levels of stress and cortisol on memory compound over time. Many different studies using all sorts of stressors have found that chronic stress can impair learning and memory and is even associated with the shrinkage of certain brain structures in humans (Conrad, 2010). Fortunately, those same studies have shown that this shrinkage is reversible. On the basis of these studies, neuroscientists would likely predict that high levels of stress in students in classrooms would be an impediment to learning, and removing some stressors could facilitate it.

\section{HOW ARE MEMORIES STORED AND RETRIEVED?}

For learning to be useful and affect behavior, once the learning is complete and synaptic connections are strengthened, memories must be stored and then retrieved when needed. While much is still to be discovered, neuroscientists propose that memories are stored in groups of neurons that all become strongly connected to each other during learning and synaptic plasticity. Just as learning to perform a certain protocol in a biology lab course, for example, might tie together many different types of information, such as remembering the quantities of chemicals used, the motions for combining them, and the look of the product once the protocol is completed, the neuronal memory ensemble may include neurons that are physically located in many different places in the brain that nevertheless are synaptically connected and that increase the strength of their connections to each other during learning (Ishai et al., 2000). Memories are retrieved through reactivation of the neurons whose synapses were altered in the initial creation of a memory, particularly in the time shortly after that memory was created (Silva et al., 2009; Caroni et al., 2014; Goshen, 2014). In fact, recent technological advances have allowed us to reactivate certain memories and induce particular learned behaviors on demand in mice through artificial stimulation of the specific neurons that were active during the formation of those memories (Xu et al., 2012).

However, just because the neurons involved are scattered throughout the brain does not mean that synapses are altered at random whenever something new is learned. On the contrary, the plasticity that occurs after learning is specific to the particular neurons that will go on to form the memory ensemble. Scientists have found that of the tens of thousands of synapses a postsynaptic neuron may have, for the most part, only the synapses connected to a particular presynaptic neuron will be strengthened when it is fired strongly by that presynaptic neuron (Bailey et al., 2000). The specificity of synaptic plasticity may mean that learning one fact or skill may not easily or immediately translate into learning another fact or skill, even if the two facts or skills seem closely related.

In summary, then, the brain creates memories through altering the synaptic connections between specific neurons, stores them in connected ensembles of neurons, and retrieves them by reactivating those same neurons and connections. Importantly, the ability of the synapses to respond to learning experiences by undergoing synaptic plasticity is modulated by the presence of other chemical factors, such as dopamine, ACh, and cortisol, which are associated with particular emotional, environmental, and cognitive states. Some of these chemicals, such as the neurotransmitters dopamine and $\mathrm{ACh}$, are associated with attention and motivation, positively influence synaptic plasticity and learning, while other compounds associated with stress, like the hormone cortisol, negatively influence synaptic plasticity and learning. So, how can we use this information about how the brain creates and retrieves memories to understand how various teaching techniques may affect our students' brains?

\section{HOW COMMON TEACHING TECHNIQUES MAY AFFECT THE NEUROBIOLOGY OF LEARNERS' BRAINS}

We will discuss here several different techniques that fall under the umbrella of "scientific teaching" and how they may affect the neurobiology of learning. We will do this by introducing four different hypothetical students-Alessa, Joe, Morgan, and Elijah-and their experiences in a traditionally taught first-year introductory biology class that lacks these techniques. The four techniques that we will focus on are frequent homework, concept maps, problem-based learning, and culturally diverse examples, although we will also briefly discuss other techniques that may take advantage of similar neural processes as these four (Table 1). For each technique, we will first present the student's experience in context, then show evidence from science education and psychology research for why the technique might address the student's difficulties, and finally discuss the likely neurobiological basis for why the technique may be effective.

\section{What Might Be the Effect of Frequent, Actively Engaging Homework?}

Imagine a student, Alessa, a first-term freshman who hopes to major in biology. Like many traditionally taught classrooms, Alessa's class assigns only textbook reading for homework. She wants to do well in her first science class, so she follows the syllabus's advice to read the textbook chapters. However, her busy life means that the reading tends to happen after the corresponding lecture rather than before. Every time, the reading feels reassuringly similar to what was said in lecture, which makes her feel satisfied with her studying and prepared for her first midterm. During the exam, however, she realizes that something is wrong. Somehow the knowledge that seemed so familiar when she read the textbook now seems to hover just out of reach in her mind. The worst experiences came when the test asked her to solve problems. She had thought that reading through the examples her teacher worked through in class would be enough, but somehow that did not translate into being able successfully complete those problems on the exam. Afterward, she asks herself, "Didn't I do what the syllabus asked me to do? Maybe I didn't read enough." She vows to spend more time on rereading her book and her notes.

Could having frequent, actively engaging homework assignments have helped Alessa learn more from her class? Alessa, like many students, believes that, by reading the textbook, she was doing an adequate job of absorbing knowledge. However, many psychology studies have confirmed that mere passive 
TABLE 1. Various teaching techniques and their possible neuronal bases

\begin{tabular}{|c|c|c|}
\hline $\begin{array}{l}\text { Neuroscientific principle discussed } \\
\text { in this Feature }\end{array}$ & $\begin{array}{c}\text { Psychological or educational findings or ideas } \\
\text { that may correspond to the neuroscientific } \\
\text { principle }\end{array}$ & $\begin{array}{l}\text { Teaching techniques that may harness the } \\
\text { corresponding principle }^{\mathrm{a}}\end{array}$ \\
\hline \multirow{3}{*}{$\begin{array}{l}\text { Synaptic plasticity is specific to the } \\
\text { particular neurons that are active } \\
\text { together. }\end{array}$} & \multirow{3}{*}{$\begin{array}{l}\text { Active forms of studying improve test performance } \\
\text { over passive forms. } \\
\text { Deliberate practice is important for gaining } \\
\text { expertise. }\end{array}$} & Frequent, active homework \\
\hline & & Deploying varied types of assessments \\
\hline & & $\begin{array}{l}\text { Giving students time in class to discuss, write, and } \\
\text { solve problems }\end{array}$ \\
\hline $\begin{array}{l}\text { Memories are encoded as synaptic } \\
\text { networks. }\end{array}$ & $\begin{array}{l}\text { Encoding knowledge relationally helps in } \\
\text { remembering it. }\end{array}$ & $\begin{array}{l}\text { Activities that ask students to compare, synthesize, } \\
\text { and evaluate }\end{array}$ \\
\hline \multirow{2}{*}{$\begin{array}{l}\text { Dopamine and ACh, released during } \\
\text { states of motivation and attention, } \\
\text { boost synaptic plasticity. }\end{array}$} & \multirow[t]{2}{*}{ Motivation and attention increase learning. } & Problem-based learning \\
\hline & & $\begin{array}{l}\text { Tailoring examples and activities to identified } \\
\text { student interests }\end{array}$ \\
\hline
\end{tabular}

Middle: psychological or educational findings or ideas that may correspond to the neuroscientific principle.

${ }^{a}$ Techniques discussed at length in the text are bolded.

exposure to knowledge, such as rereading a previously read passage, is not very effective at creating memories (Roediger and Butler, 2011). More fundamentally, passive strategies such as listening and reading seem to do a poor job of developing higher-order thinking skills like problem solving, synthesis or evaluation, even when the material is designed to explain or model those skills (Zoller, 1993). Conversely, psychologists have found that an effective way to reinforce a memory is to retrieve or reconstruct it (Roediger and Butler, 2011). Moreover, research in many domains shows that fostering learning involves deliberate practice of the skills involved; in other words, to teach problem solving, we must give students many problems to solve (Ericsson et al., 2003). Frequent homework can be an opportunity to give students that practice. Studies suggest that assigning homework in college biology classes can increase performance (Lefcort and Eiger, 2003; Orr and Foster, 2013; Carnegie, 2015). Indeed, frequent, active homework that consists of writing or problem solving is an important part of the high or moderate course structure that has been shown to reduce achievement gaps for students from underrepresented groups and to improve learning for all students (Freeman et al., 2011; Eddy and Hogan, 2014).

What do we know about the neurobiology of learning and memory that might help explain why homework can be effective in preventing the problems Alessa experienced in her exam? The difficulty students have when translating the knowledge they obtained by reading or listening into usable skills makes more sense in the light of what is known about the specificity of neural plasticity. When Alessa reread her textbook, she was probably reinforcing particular connections between the book's wording and her class material. Those may not have been the exact connections that would have been useful for associating the book's wording and how to solve biology problems or even for associating the exam's wording and her class material. Instead, if she had been assigned active homework, she might have practiced the skills she needed to succeed. Of course, there are many ways instructors can allow their students to practice skills, including using varied types of assessments and giving students time in class to discuss, write, and solve problems.

\section{What Might Be the Effects of Using Concept Maps?}

Unlike Alessa, Joe, one of Alessa's classmates, knows going into the exam that he will be in trouble. All term, the sheer number of facts has been making his head swim. By now, he has highlighted every single detail and vocabulary word in his textbook, and every time he opens it to study he feels like he is slowly sinking into a sea of neon yellow ink. The test confirms that he is drowning: on any short-response question that asks him to analyze, contrast, or argue, he has no idea where to even start, so he spills out onto the paper all the facts he can muster that relate even tangentially to the prompt. His strategy gets him enough partial credit to pass the exam, but at heart he is still confused about how all the pieces fit together. In Joe's next biology course, the professor teaches as if the students have mastered the introductory material, but Joe finds the lectures difficult to follow, because he has lost so many fragments of the necessary background knowledge.

Could concept maps have helped Joe? One of Joe's problems is that his biology course presented him with lots of details, which he gamely tried to memorize, but he did not have a big-picture view that would allow him to classify and organize those details. As instructors, we already know that all of biology is interconnected, but novices like our incoming freshmen do not. They see biological knowledge as being made up of facts that are disconnected from one another and from their everyday lives instead of something that must be organized using deep biological concepts (Semsar et al., 2011; Smith et al., 2013). When students create concept maps, they must explicitly link biological concepts and ideas to one another, countering the tendency to view each detail separately (Allen and Tanner, 2003b). Many (but not all) educational studies have 
shown that making concept maps enhances comprehension and recall of class material compared with strategies such as listening to lectures or rereading (Nesbit and Adesope, 2006; but see Karpicke and Blunt, 2011).

What do we know about the neurobiology of learning and memory that might help explain why concept maps can be effective in preventing the problems Joe encountered? Memories are encoded as synaptic networks and are retrieved when some of the neural connections are reactivated, which prompts the reactivation of the entire network to which they belong. It is logical, then, that a memory that has many connections to other memories would be easier to retrieve than a memory that has only a few entry points, because there would be more ways to reactivate the former. Therefore, explicitly connecting a piece of biology knowledge to other information in the course or the real world should make that piece of knowledge easier to remember. If Joe's instructor had required students to create concept maps, Joe might have spent more time thinking about and relating biological concepts to one another and to previous knowledge in the course or in the outside world, clarifying his understanding and making all of it easier to remember for his next biology class. Other strategies for having students connect the class material to their preexisting knowledge or to what they have learned previously include using appropriate preassessments and designing class activities that explicitly ask students to compare, synthesize, and evaluate.

\section{What Might Be the Effects of Problem-Based Learning?}

Morgan is another freshman student in Alessa and Joe's biology class. Morgan is laser-focused on the career goal that she has had since she was a small child: being a doctor. Initially, Morgan was fairly excited about her introductory biology course, hoping that it would connect basic biology to her interest in human health. However, when the instructor comes to evolution and the diversity of life, she loses all her enthusiasm. "This is so boring," she thinks. "All of this happened so slowly and so long ago. How can it be relevant to me or my future patients?" Although she crams for the exams just enough to maintain her grade point average, in a year, she will remember very little of the material on evolution.

Could problem-based learning have helped Morgan retain more of the material that was covered in the class? In problem-based learning, learning is initiated by, and structured around, complex situations (Allen and Tanner, 2003a). Importantly, they typically connect science content to situations the learners may encounter outside school, including in future professional contexts, or to broader societal contexts and concerns (Allen and Tanner, 2003a; Chamany et al., 2008). Studies of classes that use problem-based learning report positive effects on class attendance, student retention, retaining knowledge, and conceptual understanding, suggesting that students enjoy this form of teaching and learn from it (Allen and Tanner, 2003a; Prince and Felder, 2007).

What do we know about the neurobiology of learning and memory that might help explain some of the effectiveness of problem-based learning? Neurobiologists have shown that motivation and attention, which problem-based learning promotes, are associated with the release of dopamine and ACh. In turn, these neurotransmitters greatly bolster the formation of new synaptic connections. Because of Morgan's perception that the evolution material is boring and lacks relevance to her goals, her brain may not have released many of these chemicals as she was studying, potentially hampering her learning. Perhaps if her instructor had introduced evolution with a problem about antibiotic resistance, Morgan may have realized that evolution does have applications for human health and may have been more eager about and attentive to the material. Problem-based learning is not the only way to engage students, of course; for example, instructors can ask the students at the beginning of the term about their personal and professional interests and tailor examples, questions, and classroom activities to fit those interests. Perhaps key is that it is important to have the students provide information on what they find intriguing rather than relying purely on the instructor's intuition, as our interests and motivations may not be the same as those of our students.

\section{What Might Be the Effects of Using Culturally Diverse Examples?}

Elijah is also in the same first-year biology class as Morgan, Joe, and Alessa. He is excited and proud to be there, as he is the first person in his family to go to college. He knows that there are not many scientists who look like him or come from his kind of background. In fact, he cannot readily think of a single one, nor are any discussed in his biology class, but he is determined to become a research scientist. However, this class has been a lot more difficult than he expected. He studies assiduously for the first exam, since he wants to prove himself, but on test day, a subtle panic takes over. He feels his heart race, and his mind seizes up and refuses to yield the answers. After that experience, he begins to wonder, "Do I really belong here?" Every time he goes to study, he feels the weight of his doubts, and remembering his biology material somehow becomes slower and more difficult. At the end of the term, he receives a "C-" and, with a heavy sense of disappointment, decides to switch his major to sociology, where he thinks he will feel more at home.

Could using culturally diverse examples have helped Elijah feel and be more successful in class? Unfortunately, many students lack personal knowledge of scientists and hold stereotypes about what scientists are like, stereotypes that are reinforced by the media and even occasionally by materials meant to promote positive views of science or scientists (Tanner, 2009a; Schinske et al., 2015). Even if students consciously reject prejudicial notions of what types of people are better at science, they may still hold unconscious beliefs that influence their actions (Greenwald and Banaji, 1995). When students reach our classrooms and do not see themselves or issues of concern to their communities, they might reasonably conclude that they do not belong in biology. Such concerns are one of the primary drivers behind the lower retention rates of women and minority students in science (Tanner and Allen 2007; Tanner, 2009a). While worries about belonging in science can operate over long timescales and influence large decisions like one's choice of major, they can also influence day-to-day performance in the classroom. It is well known that people who are part of groups that are negatively stereotyped are at risk of confirming those stereotypes, especially in high-stress situations, a phenomenon called stereotype threat (Steele, 1997). Stereotype threat is thought to impede performance by interfering with learning and working memory (Schmader et al., 2008). In contrast, by 
using culturally diverse examples, we can show that we welcome all of our students into our classes and establish an environment that promotes students' sense that they belong in science. Introducing the stories of diverse scientists in the classroom can both increase students' ability to personally relate to scientists and improve their grades (Schinske et al., 2016).

What do we know about the neurobiology of learning and memory that might help explain the effectiveness of using culturally diverse examples in class materials? People who are scared produce the hormone cortisol. The exam was extremely stressful for Elijah, both because of its difficulty and possibly because he was being affected by stereotype threat, and he almost certainly was secreting a very high level of cortisol. In fact, it is known that students who face stereotype threat exhibit much larger increases in blood pressure and cortisol levels in situations in which they are being evaluated, like taking a test, than students who do not face that threat (Blascovich et al., 2001; Townsend et al., 2011). After the exam, Elijah probably continued to have increased cortisol levels because of his worries about his class performance and longer-term concerns about belonging in science. His subsequent difficulties with absorbing the biology material are consistent with the effects that persistently high levels of cortisol have on neural plasticity. Using culturally diverse examples may have mitigated some of the effects of high stress levels by reassuring Elijah that he belongs in science. There also are other interventions that act against high stress levels. Even one-time, 15-minute exercises have been shown to counteract the negative effects of stereotype threat for months or years if the exercise allows students to affirm their values or attribute worries about belonging to external factors such as the transition to college rather than to their personal or racial identities (Cohen et al., 2006; Yeager and Walton, 2011). We can also reduce students' stress and increase their sense of belonging in the classroom by employing equity strategies such as giving all students the chance to think and talk about science and building fair and inclusive communities (Tanner, 2013).

\section{NEUROBIOLOGICAL REANALYSIS OF THE THINK-PAIR-SHARE}

Now knowing some ways that active learning can affect the brain, let us reanalyze the "simple" think-pair-share and see how the neural processes outlined earlier can come together to promote learning. In a think-pair-share, the questions posed to the students are usually interesting and motivating to provide a rich basis for thought and discussion. By gaining the students' interest and attention, we may be promoting release of neurotransmitters such as dopamine and ACh that enhance neural plasticity. Such questions may also prompt students to connect the material under study to previously learned information or real-world issues, possibly encouraging the formation of neural networks that can promote retrieval of the material in the future. In addition, as students are writing about and discussing the questions with their peers, they are practicing the problem-solving and thinking skills necessary for gaining expertise in a subject. In other words, they may be engaging not only the parts of their brain responsible for reciting semantic information but also those important in developing skills and habits. Finally, it is important to note what is not going on during a think-pair-share. Think-pair-shares are low-stakes and involve the participation of the entire class. The friendly and communal atmosphere that regular think-pair-shares promote may increase belonging and decrease stress, potentially reducing the amount of cortisol released in student brains and removing a factor that can impede neural plasticity and learning.

\section{WHAT MIGHT TEACHING AND LEARNING LOOK LIKE AS NEUROSCIENCE ADVANCES?}

Teaching and learning are fundamentally neurobiological phenomena. However, while neurobiologists have figured out the basics behind how the brain creates and stores memories, there is still much more to discover. For example, there is currently very little neurobiology research that might explain how concepts as important to learning as metacognition and knowledge organization might be expressed in the brain. Future advances in neuroscience will almost certainly allow us to more easily investigate how complex phenomena like these are represented in the brain and how they affect synaptic plasticity. In addition, currently, a significant portion of our knowledge linking learning to cellular and molecular changes in the brain is indirect, deriving from animal studies or studies conducted in the confinement of a magnetic resonance imaging scanner. In the future, we may be able to look into the human brain in real time and get more direct information about how synapses and circuits change in students as they learn.

Because teaching and learning arise from properties of the human brain, the ability of a teaching technique to harness the processes in a student's brain that support the formation and retrieval of long-term memories will help determine that technique's effectiveness in promoting that student's learning. As we learn more about the brain, we will increasingly be able to use the results of neurobiological studies to more effectively select and develop new pedagogical techniques. Translating the results of neuroscience to the classroom will help future instructors truly teach their students from the inside out.

\section{ACKNOWLEDGMENTS}

We thank Dr. Robin Wright for her early inspiration and conversations about this Feature. We also thank Natalia Caporale, Sara Brownell, Colin Harrison, Sarah Bissonnette, Kristin de Nesnera, Rhea Kimpo, and Henry Mahncke for helpful ideas and discussion.

\section{REFERENCES}

Allen D, Tanner KD (2003a). Approaches to cell biology teaching: learning content in context-problem-based learning. Cell Biol Educ 2, 73-81.

Allen D, Tanner KD (2003b). Approaches to cell biology teaching: mapping the journey-concept maps as signposts of developing knowledge structures. Cell Biol Educ 2, 133-136.

Azevedo FA, Carvalho LR, Grinberg LT, Farfel JM, Ferretti RE, Leite RE, Jacob Filho W, Lent R, Herculano-Houzel S (2009). Equal numbers of neuronal and nonneuronal cells make the human brain an isometrically scaled-up primate brain. J Comp Neurol 513, 532-541.

Bailey CH, Giustetto M, Huang YY, Hawkins RD, Kandel ER (2000). Is heterosynaptic modulation essential for stabilizing Hebbian plasticity and memory? Nat Rev Neurosci 1, 11-20.

Bergmann O, Liebl J, Bernard S, Alkass K, Yeung MS, Steier P, Kutschera W Johnson L, Landen M, Druid H, Spalding KL, Frisen J (2012). The age of olfactory bulb neurons in humans. Neuron 74, 634-639. 
Bhardwaj RD, Curtis MA, Spalding KL, Buchholz BA, Fink D, Bjork-Eriksson T, Nordborg C, Gage FH, Druid H, Eriksson PS, Frisen J (2006). Neocortical neurogenesis in humans is restricted to development. Proc Natl Acad Sci USA 103, 12564-12568.

Blascovich J, Spencer SJ, Quinn D, Steele C (2001). African Americans and high blood pressure: the role of stereotype threat. Psychol Sci 12, 225229.

Bruer JT (2006). Points of view: on the implications of neuroscience research for science teaching and learning: are there any? A skeptica theme and variations: the primacy of psychology in the science of learning. Cell Biol Educ 5, 104-110.

Carnegie J (2015). Use of feedback-oriented online exercises to help physiology students construct well-organized answers to short-answer questions. CBE Life Sci Educ 14, ar25.

Caroni P, Chowdhury A, Lahr M (2014). Synapse rearrangements upon learning: from divergent-sparse connectivity to dedicated sub-circuits. Trends Neurosci 37, 604-614.

Chamany K, Allen D, Tanner KD (2008). Making biology learning relevant to students: integrating people, history, and context into college biology teaching. CBE Life Sci Educ 7, 267-278.

Cohen GL, Garcia J, Apfel N, Master A (2006). Reducing the racial achievement gap: a social-psychological intervention. Science 313, 1307-1310.

Conner JM, Culberson A, Packowski C, Chiba AA, Tuszynski MH (2003). Lesions of the basal forebrain cholinergic system impair task acquisition and abolish cortical plasticity associated with motor skill learning. Neuron 38, 819-829.

Conrad CD (2010). A critical review of chronic stress effects on spatial learning and memory. Prog Neuropsychopharmacol Biol Psychiatry 34, 742 755

de Kloet ER, Oitzl MS, Joels M (1999). Stress and cognition: are corticosteroids good or bad guys? Trends Neurosci 22, 422-426.

Deligiannidi K, Howard-Jones PA (2015). The neuroscience literacy of teachers in Greece. Procedia Soc Behav Sci 174, 3909-3915.

Eddy SL, Hogan KA (2014). Getting under the hood: how and for whom does increasing course structure work? CBE Life Sci Educ 13, 453-468.

Ericsson KA, Krampe RT, Tescher-Romer C (2003). The role of deliberate practice in the acquisition of expert performance. Psychol Rev 100, 363406.

Everitt BJ, Robbins TW (1997). Central cholinergic system and cognition. Annu Rev Psychol 48, 649-684.

Freeman S, Eddy SL, McDonough M, Smith MK, Okorafor N, Jordt H, Wenderoth MP (2014). Active learning increases student performance in science, engineering, and mathematics. Proc Natl Acad Sci USA 111, 8410-8415

Freeman S, Haak D, Wenderoth MP (2011). Increased course structure improves performance in introductory biology. CBE Life Sci Educ 10, 175186.

Froemke RC, Carcea I, Barker AJ, Yuan K, Seybold BA, Martins ARO, Zaika N, Bernstein $H$, Wachs M, Levis PA, et al. (2013). Long-term modification of cortical synapses improves sensory perception. Nat Neurosci 16, 79-88.

Goshen I (2014). The optogenetic revolution in memory research. Trends Neurosci 37, 511-522.

Goswami U (2006). Neuroscience and education: from research to practice? Nat Rev Neurosci 7, 406-413.

Greenwald A, Banaji M (1995). Implicit social cognition: attitudes, self-esteem, and stereotypes. Psych Rev 105, 4-27.

Hartley D (1749). Observations on Man, His Frame, His Duty, and His Expectations, vol. 2, Bath and London: Samuel Richardson.

Hebb DO (1949). The Organization of Behavior: A Neuropsychological Theory, New York: Wiley

Herculano-Houzel S (2002). Do you know your brain? A survey on public neuroscience literacy at the closing of the decade of the brain. Neuroscientist 8, 98-110

Hermida MJ, Segretin MS, García AS, Lipina SJ (2016). Conceptions and misconceptions about neuroscience in preschool teachers: a study from Argentina. Educ Res 58, 457-472.

Holtmaat A, Svoboda K (2009). Experience-dependent structural synaptic plasticity in the mammalian brain. Nat Rev Neurosci 10, 647-658.
Howard-Jones PA (2014). Neuroscience and education: myths and messages. Nat Rev Neurosci 15, 817-824.

Howard-Jones PA, Franey L, Mashmoushi R, Liao Y-C (2009). The neuroscience literacy of trainee teachers. British Educational Research Association Annual Conference, held September 2-5, 2009, in Manchester, England.

Ishai A, Ungerleider LG, Martin A, Haxby JV (2000). The representation of objects in the human occipital and temporal cortex. J Cog Neurosci 12 35-51.

James S. McDonnell Foundation (2007). The Santiago Declaration. www .jsmf.org/santiagodeclaration/ (accessed 24 September 2015)

Karlsson MP, Frank LM (2008). Network dynamics underlying the formation of sparse, informative representations in the hippocampus. J Neurosci 28, 14271-14281.

Karpicke JD, Blunt JR (2011). Retrieval practice produces more learning than elaborative studying with concept mapping. Science 331, $772-$ 775 .

Lefcort H, Eiger SM (2003). Preparatory versus practice homework: university biology students compare the two. J Coll Sci Teach 33, $16-18$.

Lupien SJ, McEwen BS (1997). The acute effects of corticosteroids on cognition: integration of animal and human model studies. Brain Res Rev 24, $1-27$.

Lyman $F$ (1981). The responsive classroom discussion: the inclusion of all students. In: Mainstreaming Digest, ed. A Anderson, College Park: University of Maryland, 109-113.

Megias M, Emri ZS, Freund TF, Gulyas AI (2001). Total number and distribution of inhibitory and excitatory synapses on hippocampal CA1 pyramidal cells. Neuroscience 102, 527-540.

Morris RG, Anderson E, Lynch GS, Baudry M (1986). Selective impairment of learning and blockade of long-term potentiation by an N-methyl-D-aspartate receptor antagonist, AP5. Nature 319, 774-776.

Nesbit JC, Adesope OO (2006). Learning with concept and knowledge maps: a meta-analysis. Rev Educ Res 76, 413-448.

Orr R, Foster S (2013). Increasing student success using online quizzing in introductory (majors) biology. CBE Life Sci Educ 12, 509-514.

Prince M, Felder R (2007). The many faces of inductive teaching and learning. J Coll Sci Teach 17, 14-20.

Reed A, Riley J, Carraway R, Carrasco A, Perez C, Jakkamsetti V, Kilgard MP (2011). Cortical map plasticity improves learning but is not necessary for improved performance. Neuron 70, 121-31.

Roediger HL, Butler AC (2011). The critical role of retrieval practice in long term retention. Trends Cogn Sci 15, 20-27.

Schinske J, Cardenas M, Kaliangara J (2015). Uncovering scientist stereotypes and their relationships with student race and student success in a diverse, community college setting. CBE Life Sci Educ 14, ar35.

Schinske JN, Perkins H, Snyder A, Wyer M (2016). Scientist spotlight homework assignments shift students' stereotypes of scientists and enhance science identity in a diverse introductory science class. CBE Life Sci Educ 15, ar47.

Schmader T, Johns M, Forbes C (2008). An integrated process model of stereotype threat effects on performance. Psychol Rev 115, 336-356.

Schultz W, Dickinson A (2000). Neuronal coding of prediction errors. Annu Rev Neurosci 23, 473-500.

Semsar K, Knight JK, Birol G, Smith MK (2011). The Colorado Learning Attitudes about Science Survey (CLASS) for use in biology. CBE Life Sci Educ $10,268-278$.

Shatz C (1992). The developing brain. Sci Am 267, 60-67.

Silva AJ, Zhou Y, Rogerson T, Shobe J, Balaji J (2009). Molecular and cellular approaches to memory allocation in neural circuits. Science 326, $391-$ 395.

Smith JI, Combs ED, Nagami PH, Alto VM, Goh HG, Gourdet MAA, Hough CM, Nickell AE, Peer AG, Coley JD, Tanner KD (2013). Development of the Biology Card Sorting Task to measure conceptual expertise in biology. CBE Life Sci Educ 12, 628-644

Spalding KL, Bergmann O, Alkass K, Bernard S, Salehpour M, Huttner HB, Bostrom E, Westerlund I, Vial C, Buchholz BA, et al. (2013). Dynamics of hippocampal neurogenesis in adult humans. Cell 153, 1219-1227. 
Steele CM (1997). A threat in the air: how stereotypes shape intellectual identity and performance. Am Psychol 52, 613-629.

Takeuchi T, Duszkiewicz AJ, Morris RGM (2014). The synaptic plasticity and memory hypothesis: encoding, storage and persistence. Phil Trans R Soc B 369, 1-14.

Tanner KD (2009a). Learning to see inequity in science. CBE Life Sci Educ 8, 265-270.

Tanner KD (2009b). Talking to learn: why biology students should be talking in classrooms and how to make it happen. CBE Life Sci Ed 8, 89-94.

Tanner KD (2013). Structure matters: twenty-one teaching strategies to promote student engagement and cultivate classroom equity. CBE Life Sci Educ 12, 322-331.

Tanner KD, Allen D (2007). Cultural competence in the college biology classroom. CBE Life Sci Educ 6, 251-258.

Townsend SSM, Major B, Gangi CE, Mendes WB (2011). From "in the air" to "under the skin": cortisol responses to social identity threat. Pers Soc Psychol Bull 37, 151-164.
Wiesel TN, Hubel DH (1963). Effects of visual deprivation on morphology and physiology of cells in the cat's lateral geniculate body. J Neurophysiol 26, 978-993.

Williams RW, Herrup K (1988). The control of neuron number. Annu Rev Neurosci 11, 423-453.

Xu L, Ramirez S, Pan PT, Puryear CB, Govindarajan A, Deisseroth K, Tonegawa $S$ (2012). Optogenetic stimulation of a hippocampal engram activates fear memory recall. Nature 484, 381-385.

Xu T, Yu X, Perlik AJ, Tobin WF, Zweig JA, Tennant K, Jones T, Zuo Y (2009) Rapid formation and selective stabilization of synapses for enduring motor memories. Nature 462, 915-919.

Yang G, Pan F, Gan W-B (2009). Stably maintained dendritic spines are associated with lifelong memories. Nature 462, 920-924.

Yeager DS, Walton GM (2011). Social-psychological interventions in education: they're not magic. Rev Educ Res 81, 267-301.

Zoller U (1993). Are lecture and learning compatible? Maybe for LOCS: unlikely for HOCS. J Chem Educ 70, 195-197. 